\title{
Realizing Powerful Social Studies Learning through Map Literacy
}

\author{
Nuansa Bayu Segara \\ Universitas Swadaya Gunung Djati \\ Cirebon, Indonesia \\ nuansasegara88@fkip-unswagati.ac.id \\ Enok Maryani \\ Universitas Pendidikan Indonesia \\ Bandung, Indonesia \\ enokmaryani@upi.edu
}

\author{
Mamat Ruhimat \\ Universitas Pendidikan Indonesia \\ Bandung, Indonesia \\ mamat_ruh@yahoo.co.id
}

\begin{abstract}
Map is required many disciplines to present information. Various professions and occupations require maps to support their activities. Social Studies as the first subject in schools has a great responsibility to teach and build map literacy. Presenting map as an alternative media and learning resources and developing it into a learning model are strategic efforts to realize a powerful Social Studies learning. A concept from the United States which is adequate in affecting curriculum of the latest social studies education prevailing in Indonesia today. social studies are the first subject to introduce map in school, has a great responsibility to teach and build map literacy. This article aims to identify maps usage in Indonesia secondary school IPS lessons. It would reveal teachers perception on assumption that IPS will be powered by the application of map literacy in learning. Research result exhibits that the utilization of map has not been optimal because the map is still limited as a medium to merely present a location. The majority of teachers are very confident that by utilizing maps in social studies learning would make social studies meaningful, challenging, value-based, integrative and active (powerful). These results ultimately suggest that map literacy is a necessity for learners in Indonesia and teachers are very supportive for the development for a model of learning-based literacy map that is able to realize a powerful IPS learning.
\end{abstract}

Keywords: map literacy, powerful social studies, social studies learning

\section{INTRODUCTION}

The purpose of social studies learning in Indonesia is to prepare the students to have the attitude, knowledge, and skills that are useful for the complex future life. In this era, learners essentially need this subject in accordance with the higher demand of world competence. In facing various problems, they need to have a complex, critical, and solution seeking thought. They also need the skills to act quickly, effectively and efficiently [1]. All of the aforementioned abilities can be built slowly and continuously through the social studies in school. America through NCSS (National Council for the Social Studies) has the paradigm of social studies learning that needs to be referenced. NCSS (1994) had the idea of "Powerful Teaching and Learning in the Social Studies". In 2016, NCSS reaffirmed the importance of powerful social studies in a position statement. The Powerful Teaching and Learning in the Social Studies is considered to be realized when it applies the principles of Meaningful, Integrative, Value-Based, Challenging, and Active system [2]. By examining curriculum framework of social studies in Indonesia, there are many similarities of principles applied in the learning process. These are believed to improve the learning quality of social studies and help learners to achieve the learning objectives.

By referring to the strategy initiated by NCSS and by tracing the source and results of previous studies, one of the methods to create a powerful social study is to use maps in the learning process. The utilization of maps in social studies can improve the knowledge, attitudes, values, and learners skills effectively [3]-[6]. Based on these findings, it can be assumed that maps possess great opportunity in creating a powerful social study in Indonesia.

The use of maps provides an ideal base of interdisciplinary science/social studies [7]. Using a map in learning process would be ideal if it is interdisciplinary. This means that map is able to unite different disciplines in social studies in accordance with the integrative principles of powerful social studies. Learning social studies through map literacy will be useful to improve students' skills. Utilizing maps is needed in this digital era, therefore, this activity will be meaningful for them. Maps are essential geographic tools, and a variety of them are needed to foster critical thinking about them [8]. Basic map skills to be ingrained upon students in their Social Studies course bear significance for their development spatial perception and global positioning skills, which will then aid them in their future by facilitating their entrance into a globalizing world [9]. 
This article aims to show the actual conditions of maps utilization in social studies and describes teachers' perception in Cirebon regarding this research central problem. "Could map literacy can realize a powerful social study?" The actual conditions of map utilization in social studies learning is identified and tailored to the needs of this research which includes planning, process, and evaluation. On the other hands, the teachers' perception was measured by the aspects and indicators of social studies powerful learning. The factors were indicators such as Meaningful, Integrative, Value-Based, Challenging, and Active [2].

\section{METHODS}

\section{A. Data Collection}

The target population in this study was the entire social studies teacher working in the secondary schools in Cirebon. The junior high schools (public and private) registered in the Education Board of Cirebon are 45 schools, but the schools which were considered to be active and worthy of the research are only 36 units. By calculating the determinant coefficient of 0,05 , the number of samples taken was 68 teachers. The data were also collected only from 61 teachers sue to approval problems with the principal and the unwillingness of the teacher itself. There were two types of instruments used in the data collection: first, to identify the actual condition of map utilization in social studies learning, a questionnaire with two choices of answers and a reason column; second, scale rating to measure the teachers' perception towards powerful social studies through map literacy.

\section{B. Data Analysis}

Data were analyzed using a descriptive method. In order to identify the actual condition of map utilization on social studies in Cirebon, a percentage method was used. As for the teachers' perception, the analysis was carried out with scoring technique. There were also validity and reliability test using a partial least square procedure. Furthermore, the score was calculated and identified teachers' perception percentage level.

\section{RESULT AND DISCUSSION}

\section{A. Validity and Reliability}

Second Order Confirmatory Factor Analysis was used with the help of SmartPLS 3.0 to examine the procedure of validity and reliability test on teachers' perception towards map utilization to create a powerful social study. There were several reasons why this Partial Least Square technique is used to test the validity construct of teachers' perception. In fact, the construct used is not derived from the theory that has been tested therefore it is still a predictive instrument. The data did not need to be distributed normally and the parameter estimation could be directly performed without the requirement of the goodness of fit. To test the constructs, small sample size ( $<100$ participants) is seen to be very appropriate when it is operated together with partial least square [10].

There were also several criteria which are needed to be met in order for the instrument declared valid and reliable. The values of the loading factor must be greater than 0.7 with a composite reliability score that measures the internal consistency that is above 0.6. The AVEvalue (average variance extracted) must be above 0.5 and the AVE square root value must be greater than the correlation value between latent variables. The significance of this test was done by bootstrapping procedure [11]. The following are the results of validity and reliability measurement of the teachers' perception instrument.

TABLE I. LOADING FACTOR, STANDARD ERROR, AND BOOTSTRAPPING VALUES

\begin{tabular}{cccc}
\hline & $\lambda$ & $s e$ & $\mathrm{t}$ \\
\hline Item1 & 0,896 & 0,038 & 23,478 \\
\hline Item2 & 0,907 & 0,039 & 23,138 \\
\hline Item3 & 0,919 & 0,036 & 25,444 \\
\hline Item4 & 0,850 & 0,078 & 10,958 \\
\hline Item5 & 0,865 & 0,043 & 20,288 \\
\hline Item6 & 0,898 & 0,036 & 24,727 \\
\hline Item7 & 0,783 & 0,061 & 12,904 \\
\hline Item8 & 0,822 & 0,038 & 21,872 \\
\hline Item9 & 0,803 & 0,093 & 8,651 \\
\hline Item10 & 0,888 & 0,044 & 19,971 \\
\hline Item11 & 0,828 & 0,078 & 10,663 \\
\hline Item12 & 0,761 & 0,059 & 12,796 \\
\hline Item13 & 0,807 & 0,066 & 12,314 \\
\hline Item14 & 0,898 & 0,028 & 32,187 \\
\hline Item15 & 0,795 & 0,097 & 8,161 \\
\hline
\end{tabular}

Based on analysis result, all indicators of the construct have a loading factor value greater than 0,70 which means that all indicators were valid. All 15 indicators that make up the dimensions of meaningful, challenging, value-based, integrative and active had a very good validity. Regarding the instrument's reliability level of teachers' perception, several values need further observations such as average variance extracted (AVE), composite reliability, and Cronbach's alpha. It should be noted that the value of Cronbach's alpha on PLS was underestimated compared to the Dillon-Goldstein's rho. The value of composite reliability is described in the following table [10], [12].

TABLE II. AVE, STANDARD ERROR, BOOTSTRAPPING VALUES, COMPOSITE RELIABILITY AND CRONBACH'S ALPHA VALUES

\begin{tabular}{cccccc}
\hline & AVE & se & t & $\begin{array}{c}\text { Dillon } \\
\text { rho }\end{array}$ & $\begin{array}{c}\text { Cronbach's } \\
\text { alpha }\end{array}$ \\
\hline Active & 0,823 & 0,059 & 14,071 & 0,933 & 0,893 \\
\hline Challenging & 0,759 & 0,073 & 10,432 & 0,904 & 0,841 \\
\hline Integrative & 0,644 & 0,067 & 9,645 & 0,845 & 0,724 \\
\hline Meaningful & 0,684 & 0,077 & 8,841 & 0,866 & 0,767 \\
\hline $\begin{array}{c}\text { Value- } \\
\text { Based }\end{array}$ & 0,696 & 0,079 & 8,837 & 0,873 & 0,781 \\
\hline
\end{tabular}


In line with the results of AVE value greater 0.5 in the table above, exhibits instruments to measure teachers' perception possess good construct validity. As for the construct reliability through the value of Composite Reliability (Dillon-Goldstein's rho) and Cronbach's alpha, it indicates that the instrument of teachers' perception is qualified as a very reliable measurement instrument. This happens due to the calculation of DillonGoldstein's rho and Cronbach's alpha that is exceeding 0.7 as the lowest requirement of instrument reliability.

\section{B. The Factual Condition of Social Studies Learning}

The age composition of social studies teacher in Cirebon is fairly even in every school. Generally, there is a senior and junior social studies teacher. Their average experience of teaching in Cirebon is 16,33 years. The longest teaching experience is 33 years and the shortest by 2,5 years. This means that, generally, the secondary school social studies teacher in Cirebon has a considerable experience. However, the burden of teaching social studies in Cirebon is also quite high. On the average, the total working hours of them teaching in Cirebon is as much as 22,7 hours/week. This is because the teachers are striving to meet the 24 hours teaching demand (the teaching terms in Indonesia). The results which are obtained from the survey exhibits that $70,5 \%$ of social studies teacher in Cirebon has claimed that they teach 24 hours/week or more.

The majority of social studies teacher in Cirebon still use the 2006 curriculum. In 2016/2017 academic year, there are some schools that reimplementing the 2006 curriculum because they considered incapable to implement the curriculum of 2013. It is noted at the Ministerial Regulation No. 20 Year 2016 that all schools should have applied the rules in $2016 / 2017$ academic year. Based on the recognition of some teachers who are implementing the 2013 curriculum, it actually affects the learning process greatly in which there is a different approach. The students could be more active in the learning process and it pushes the teachers to make innovations in social studies learning.

In fact, the use of curriculum has an impact on learning model or method of social studies in the classroom. Based on data collected during the study, the conventional approach still dominates the teaching practice of social studies in Cirebon secondary schools.

Processed data exhibits almost half $(>50 \%)$ of social studies teachers in Cirebon mostly conduct lecture method in teaching social studies. Only a small part of social studies teacher who uses the discussion method in the learning process. Then, from $31,1 \%$ of the social studies teacher who uses the 2013 curriculum in the learning process, only $9,8 \%$ of them use the problem-based learning model which is recommended in the curriculum. This may imply that the use of the 2013 curriculum could not change the teacher approaches in the social studies learning process because it is still dominated by conventional approaches. In addition, the teachers are committed to the use of teaching model that involves social interaction as discussion and cooperative method.

Based on the observation of social studies teachers during the learning process, the best method to get a positive response from students is when the teacher uses discussion method. As much as $41 \%$ of teachers felt that this method is the most powerful technique to improve the quality and students interest to participate in social studies learning. In addition, cooperative learning and varied lecture are still considered to have such positive response from the students when it is applied in the learning process. Whereas, in the scientific approach which consists of the discovery learning model as well as inquiry and problem-based learning, there is a positive response from the students, at least according to the $11,5 \%$ of social studies teacher in Cirebon.

Data exhibits that social interaction-based learning method received student enthusiasm in social studies. Thus, these results reinforce the view of social constructivism that the process of interactive learning will improve the responsiveness of the students and build their knowledge faster compared with the individualized learning [3].

\section{Map Utilization in Social Studies Learning}

The use of map in social studies learning is not a new matter. Nevertheless, it is necessary to determine the optimization process of map utilization in social studies learning. The identification of this research includes map utilization in the process, planning, content development, and evaluation of social studies teaching. Teachers were given a questionnaire that questioned the extent to which they utilize map. In Table 3 describes questionnaire result.

TABLE III. MAP UTILIZATION IN SOCIAL STUDIES LEARNING

\begin{tabular}{|c|c|c|c|}
\hline No & Statement & $\begin{array}{l}\text { Yes } \\
(\%)\end{array}$ & $\begin{array}{l}\text { No } \\
(\%)\end{array}$ \\
\hline 1 & $\begin{array}{l}\text { Incorporate skills (reading and using map) on } \\
\text { the achievements of students in social studies } \\
\text { lesson plan. }\end{array}$ & 86,9 & 13,1 \\
\hline 2 & $\begin{array}{l}\text { Incorporate map as a media/learning } \\
\text { resources in the lesson plan. }\end{array}$ & 90,2 & 9,8 \\
\hline 3 & $\begin{array}{l}\text { Design your own worksheets that focus on } \\
\text { the use of a map as a learning resource. }\end{array}$ & 32,8 & 67,2 \\
\hline 4 & $\begin{array}{l}\text { Using maps to enrich the material on the } \\
\text { entire content (History, Economics, } \\
\text { Geography, Sociology) in social studies } \\
\text { learning. }\end{array}$ & 47,5 & 52,5 \\
\hline 5 & $\begin{array}{l}\text { Make map as a discussion group in social } \\
\text { studies learning. }\end{array}$ & 37,7 & 62,3 \\
\hline 6 & $\begin{array}{l}\text { Utilize map as a location bookmark in social } \\
\text { studies learning. }\end{array}$ & 95,1 & 4,9 \\
\hline 7 & $\begin{array}{l}\text { Students analyze map to know and } \\
\text { understand the distribution of spatial } \\
\text { phenomenon. }\end{array}$ & 32,8 & 67,2 \\
\hline 8 & $\begin{array}{l}\text { Facilitate students to recognize and } \\
\text { understand the disaster and mitigation } \\
\text { through the map. }\end{array}$ & 39,3 & 60,7 \\
\hline 9 & $\begin{array}{l}\text { Introduce the use of digital maps (google } \\
\text { maps, google earth, digital atlas) in social } \\
\text { studies learning. }\end{array}$ & 26,2 & 73,8 \\
\hline
\end{tabular}

Social studies teacher in Cirebon is aware that map is an important part of the learning of social studies. It was exhibited from questionnaire result. Almost every teacher incorporate map literacy skills in the learning objectives and make the map as a source/media in the lesson plan. However, the optimization of map utilization has not been performed with use of worksheets which have map within the content as a learning resource. Worksheets that are widely used by teachers just simply a collection of questions created by the publisher. Only a small percentage of teachers who design the worksheets focused on students' literacy. 
In the aspect of content development by utilizing map, more than half of the teachers reported having never used maps to develop the social studies contents which consist of multiple disciplines (History, Economics, Geography, and Sociology). They revealed that map is only appropriate for Geographic content so therefore they do not use maps in teaching History, Economics, and Sociology. It is known that only a small percentage of teachers use maps on some subjects related to other social studies. Teachers who conducted this possess knowledge that thematic maps can be used in other social studies discipline.

Map utilization in the learning process of social studies in Cirebon is still not optimal. The survey results exhibit map utilization performed by teachers only focus as a location reference. Building analytical skills of spatial phenomenon distribution, as well as recognition and understanding of disasters and mitigation, has not been widely implemented by them. The introduction and utilization of digital maps in social studies learning also still very low, only a small percentage of teachers who do so. Such factors like the lack of facilities or media are the main reason of why this method has not been practiced.

In Cirebon, the frequency of map utilization in each semester is still low. $57,4 \%$ of the teachers said that they use the map probably about 1-3 times in the learning process while only $23 \%$ of them said as much as $4-6$ times, and $19,7 \%$ of them claimed that they use map more than 6 times in one semester. The type of map which often used is a small-scale map or geographic scale. 55,7\% of the teachers used map of Indonesia as the most frequently used map in the learning process and, in the second place, is the world map that is used by $41 \%$ of the teachers followed by Asian Map used by 3,3\% of the teachers.

\section{Teacher Perception: Powerful Social Studies Through Map Literacy}

Measuring teachers' perception to use the map as a way to create a powerful social studies learning is needed. This is essential to be done to determine teachers' perception and support to realize a powerful social study. The construct of teachers' perception is taken from the paradigm of powerful social studies learning provided by NCSS. Social studies must be meaningful, challenging, value-based, integrative, and active [2]. Based on the aggregate result, the teachers' perception on "the establishment of powerful social studies learning through literacy map" has reached $79.22 \%$. In other words, teachers feel that map literacy is appropriate to be used in achieving a meaningfull, challenging, value-based, integrative, and active social studies. Teachers' perception analysis is carried out in accordance with the dimension measured. The following is a diagram that exhibits the teachers' perception of any measured dimensions.

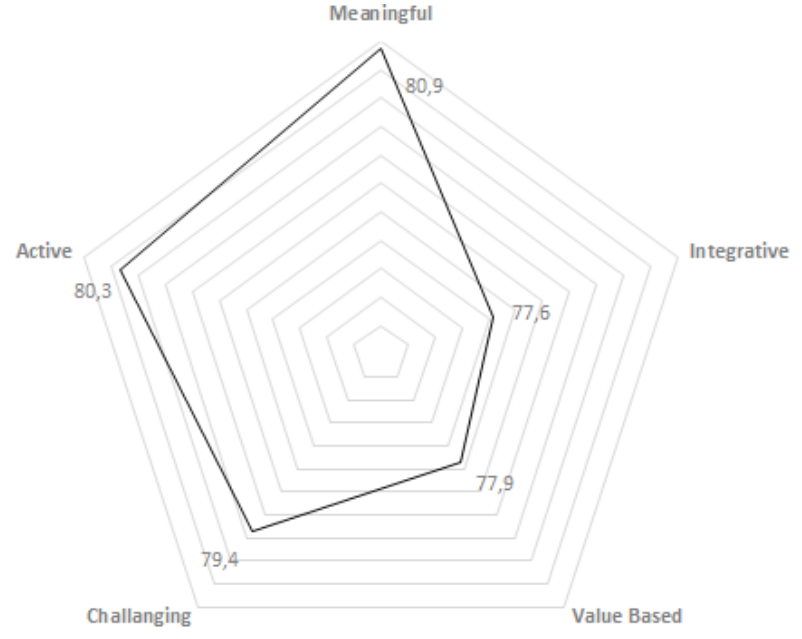

Fig. 1. Radar Graph of Teachers' Perception towards Powerful Social Studies Learning through Map Literacy

In the first dimension, social studies teachers in Cirebon have the perception that it is appropriate to use the map as a means of meaningful social studies learning. This indicates that social studies teachers have high confidence of, 1) Map utilization in social studies learning will facilitate the students to know and understand the national, regional, and global problems; 2) Map is used as a medium to recognize race, ethnicity, and nation from various places in the world; 3) The introduction of digital map through social studies learning will improve skills in recognizing space, determining location and route, as well as to travel more effectively. Those are the basis for the development of map literacy learning model. Teachers possessing such perspective and high confidence that this model can make the learning process of social studies become more meaningful. $80.9 \%$ of teachers find it very appropriate if map literacy is applied in which this will make meaningful social studies learning; this number is the highest of any other measurable dimension. Students will be greatly helped to develop the knowledge, attitudes, and values in accordance with the direction of social studies learning in Indonesia.

Social studies teachers in Cirebon conclude that map literacy in social studies learning is very suitable if it is used as a means for integrative learning. They often complain about the approach to teaching materials. Most social studies teachers come from social science education, the vast majority were from Economic Education so that it is often claimed that it is difficult to relate one content of social studies discipline with other social studies disciplines. Teachers find it very appropriate if 1) map is used to facilitate teachers and students in collaborating the material into integrated social studies learning (History, Geography, Economics, Sociology); 2) map is utilized as a learning resource to facilitate the students in performing inquiry, analyze and show the data, synthesize, and solve problems; 3) A map can be used as a link to the past, present, and future phenomena in social studies learning. These results are in line with the belief in this study that through the map, social studies learning is easier to be integrated or connected to other social studies discipline (Geography, History, Economics, and Sociology). Thus, this becomes the basis of the development of social studies education program in Indonesia. 
The third dimension is value-based. The results exhibit that social studies teacher in Cirebon believed that it is very compatible if value-based social studies learning is realized by utilizing map in the learning process. They consider that 1) map can be used in social studies learning the process as valuebased learning resources. 2) the utilization of thematic maps (map of the world conflict, a map of the independence war, a map of Indonesia monarchy) will increase the sense of humanity, respect, fairness, and respect the independence of every nation. 3 ) the use of the natural disaster map in social studies learning will build a caring attitude. This result is a capital base that social studies practitioners in schools believe that map can be useful as a medium of value-based social studies learning.

The fourth dimension in this session is challenging, which means that by utilizing map in social studies learning, will provide more challenges for the students. Social studies learning that is recommended by NCSS is able to accommodate the skills that are useful in accordance with the demand of the era. The results showed that it is appropriate to use a map in social studies learning to make students challenged. This includes the aspects of 1) using a map to understand the data and present spatial phenomena in another form such as graphs and charts; 2) using map as media and learning resources in the process can raise students' curiosity and thinking ability; 3) students can read, understand, and analyze the data on a map and present them orally to the class. Reading the spatial information in map and transforming in the form of a graph or chart is one of the elements in the indicators of spatial thinking skills. It can be concluded that the social studies teachers in Cirebon are conceptually very supportive towards this idea.

The last dimension is active, social studies are expected to facilitate the learning process centered on the students. Social studies teachers in Cirebon feel that it is appropriate to utilize map in social studies learning so that it could 1) promote the establishment of students who are active in social studies learning; 2) be used as a learning resource and a matter for discussion so that students can exchange ideas and concepts; 3 ) through the utilization of certain thematic maps, students are able to investigate the condition of man, nature, and spatial phenomena.

\section{E. Discussion}

The utilization of maps by students is an area of research that is very interesting. On the one hand, it is a large part of cognitive spatial and cognitive mapping development, while on the other hand, it is the attempt to understand the spatial relations in an environment through direct experience with external representation as in a map [13]. Through the use of map in the learning process, students could obtain many impacts. In addition to students' cognitive development, the powerful social studies can be realized so that the learning objectives can be achieved. Social studies are seen to build such kind of skill understanding and development and also facilitate students to become a long-life learner [14]. Therefore, a strong basis is needed either in theory or empirical study to realize powerful social studies learning through map literacy.

Based on the literature review, the study of map literacy has been examined several times, and an instrument for measuring map literacy had been shown to students in college [15]. This research is needed because it becomes the initial data needed to improve the literacy skills of maps at the primary school level. Because it identifies the process of map utilization in schools it will be able to know what needs to be met in order to realize the learning of social studies powerful based on map literacy. In addition, the perspective derived from the teacher, so research data is very useful for designing learning that focuses on the map literacy and in accordance with the IPS learning process shortcomings.

In contrast to the Ref [9] which identifies the learning of map and the student's map skills qualitatively from the teacher's perspective. This study identifies the learning of map in social studies quantitatively. The resulting data is more comprehensive, ranging from the teacher's general profile, curriculum development and social studies materials (especially related to map content), the frequency of map use, and the use of maps in developing student critical thinking. As well predictively questions the teacher to give perception about the utilization in learning able to improve quality of learning social studies in class.

The results of the study as described earlier have generated some points that could be the empirical basis for the realization of social studies learning through map literacy in Cirebon.

- The discussion is widely used as the method of teaching social studies which mostly received a positive response from students.

- The majority of teachers have an awareness that map is needed in the learning process.

- The utilization of map as a means of subject development is still done by the teacher.

- The majority of teachers are not yet using a map as a source of group discussion.

- The majority of teachers in utilizing a map as a location reference.

Teachers feel that it is suitable to use map in order to realize the powerful social studies (meaningful, challenging, value-based, integrative, and active).

The discussion is the method that is widely used by the majority of social studies teachers in Cirebon. This method is also able to generate a very positive response from the students so that it can be considered that realizing a powerful social study through map literacy can be done by applying a group discussion. Ref [7] carried out an investigative group in conducting a map-based learning [6]. Theoretically, the social cognitive development of Vygotsky is very compatible to be used as the basic theory of map utilization in groups. Ref [13] also recommended Vygotsky's Socio-cultural concept as one of the theories of map utilization in a learning process. Meanwhile, Ref [4] has proved that a cooperative map-based learning is more effective than the individual learning. Several articles and research also explain that sociocultural conditions could affect people's cognitive spatial development such as the differences in cultural backgrounds and places (living environment) [15]-[17].

The positive perceptions from teachers in assessing map utilization for powerful social studies learning can be used as a reinforcement of map-based social studies learning realization. In fact, there are some teachers who are very enthusiastic and willing to participate. Based on the review of the current curriculum, Geography becomes the backbone of 
social studies so that it would be relevant if map as an icon of Geography becomes one of the means to integrate social studies content with other social studies disciplines [14]. Teaching with maps means using maps to help students learn the key to social studies concepts and relationships [3]. The map could connect a variety of content in social studies so that it could be integrated into social studies teaching and learning.

Realizing powerful social studies learning through map literacy can be realized by conducting a review and learning components development. One of the ways to have a holistic development is by using the design of learning model that focuses on map utilization.

\section{CONCLUSION}

The map literacy is one of the skills required in this era. Social studies discipline has an obligation to develop those skills at school. Research result exhibits that map utilization in the social studies learning the process in Cirebon is still not optimal. Map utilization carried out by the teacher is just merely a tool to show a location. The frequency of map use in each semester is also low. In addition, factually, the learning method that is widely used by teachers, as well as the most positive response of students is a cooperative method.

Other research results show that social studies teachers in Cirebon City have a good perception of the potential in realizing powerful social studies through map literacy. This is a reinforcement that teachers need to improve the quality of learning by using and utilizing maps on social studies practices in schools.

The map should be used for developing knowledge, attitudes, values, and skills needed in this era such as spatial thinking, inquiry, and critical thinking, problem-solving, environmental awareness, social awareness, etc. Theoretically and empirically, utilizing map in social studies learning is possible. An instructional design that has a complete toolkit to facilitate the realization of powerful social studies learning through map literacy is needed. Therefore a map is not only used as a location reference but also as media and learning resources which can improve student's thought processing skills.

\section{ACKNOWLEDGMENT}

The researchers would like to thank the entire social studies teachers in Cirebon as well as to thank the promoter, copromoter, and members who always direct and guide the researchers through the process.

\section{REFERENCES}

[1] N. B. Segara, "The Urgency of Map Literacy and Spatial Thinking for Urban Society," Eur. J. Soc. Sci. Stud., vol. 1, no. 1, pp. 116-126, 2016.

[2] NCSS, "A Vision of Powerful Teaching and Learning in the Social Studies," vol. 80, no. 3, pp. 180-182, 2016.

[3] S. W. Bednarz, G. Acheson, and R. S. Bednarz, "Maps and Map Learning in Social Studies," Soc. Educ., vol. 70, no. 7, pp. 398-404, 2006.

[4] S. B. Adeyemi and E. N. Cishe, "Effects of Cooperative and
Individualistic Learning Strategies on Students' Map Reading and Interpretation," Int. J. Arts Sci., vol. 8, no. 7, pp. 383-395, 2015.

[5] S. Yousaf, S. Aziz, and H. Hassan, "Effectiveness of Maps \& Globes in Social Studies 'Teaching," Int. J. Soc. Sci. Educ., vol. 3, no. 1, pp. 183-187, 2012.

[6] T. Reed, "Thinking Maps : An Innovative Way To Increase Sixth-Grade Student Achievement In Social Studies," Capella University, Ann Arbor, 2014.

[7] G. C. Hribar, "Using Map-Based Investigations with Elementary Students," in ESRI Education GIS Conference, 2015, pp. 1-26.

[8] A. L. McCall, "Promoting Critical Thinking and Inquiry through Maps in Elementary Classrooms," Soc. Stud., vol. 102, pp. 132-138, 2011.

[9] N. Gökçe, "Social Studies in Improving Students' Map Skills: Teachers' Opinions," Educ. Sci. Theory Pract., vol. 15, no. 5, pp. 1345-1362, 2015.

[10] I. Ghozali and H. Latan, Partial Least Squares : Konsep, Teknik dan Aplikasi Menggunakan Program SmartPLS 3.0, Edisi 2. Semarang: Badan Penerbit Universitas Diponegoro, 2015.

[11] I. Ghozali, Structural Equation Modeling : Metode Alternatif Dengan Partial Least Square (PLS), Edisi 4. Semarang: Badan Penerbit Universitas Diponegoro, 2014.

[12] H. Ravand, "Partial Least Squares Structural Equation Modeling with R CB-SEM vs PLS-SEM," vol. 21, no. 11, 2016.

[13] P. Wiegand, Learning and Teaching with Maps. London and New York: Routledge Taylor\&Francis Group, 2006.

[14] G. Mindes, Teaching Young Children Social Studies, 1st ed. Westport: Praeger Publishers, 2006.

[15] K. Verma, "Geospatial Thinking of Undergraduate Students in Public Universities in The United States," Texas State University, 2014.

[16] E. P. Apostolopoulou, “Children's Map Reading Abilities In Relation To Distance Perception, Travel Time And Landscape," Eur. J. Geogr., vol. 2, no. 2, pp. 35-47, 2011.

[17] D. H. Uttal, "Maps and spatial thinking: a two-way street," Dev. Sci., vol. 3, no. 3, pp. 283-286, 2000. 
